\title{
Sivistyksen tarina aamuhämärästä iltaruskoon
}

\author{
Eero Taivalsaari: Kansallinen herätys. Kirjoituksia Suomesta.
}

VS-kustannus 2014. 394 s. ISBN: 978-952-67391-1-3

MaAliskuUssa 76-vuotiaana kuollut Eero Taivalsaari oli kansalaisaktiivi ja toisinajattelija par excellence. Hän julkaisi kymmenen tietokirjaa, muun muassa Alaston totuus markkinavoimista (1997) ja Unohdettu viisaus (2010). Hänen EU-kritiikkinsä ja hänen päätoimittamansa Näköpiiri-lehti muistetaan hyvin.

Kansallinen herätys -teoksen takakansiteksti ilmaisee jykevin sanakääntein, mistä on kyse: "Aika on käymässä vähiin. Jokainen valitsee nykymenon ja sivistyneen elämäntavan välillä - tietoisesti tai tahtomattaan. Hyvän elämän ja kansallisen eheyden tiennäyttäjiä löytyy historiasta."

Alkuluvussa s. 12-13 todetaan: "Kepeä pinnallisuus leimaa omaa aikaamme. Ihminen on vietelty henkiseen laiskuuteen. Tiedon on korvannut propaganda, oppimisen halun viihtymisen pakkomielle (- -) sivistyksen rapautumisen myötä Suomi itsenäisenä kansakuntana ei tule säilymään.”

\section{ANTIIKIN SIVISTYS LÄHTÖISIN SUOMESTA}

Kansallinen herätys on tavallaan kolme kirjaa yksissä kansissa. Alkuosa kertoo suomalaisen kansallisen herätyksen aamuhämärästä. Nykyaikaa kohti edetessään kirjoittaja ei pehmentele sanojaan kuvatessaan sivistyksen puutetta ja historiattomuutta. Lopussa pohditaan uuden, tällä kertaa globaalin ekologisen heräämisen mahdollisuutta.

Suomalaisuuden historian teoksessa aloittaa Turun akatemian heprean, kreikan ja teologian professori Daniel Juslenius (1676-1752). Häntä voi pitää suomalaisuuden ensimmäisenä julkisena puolestapuhujana, mutta häneltä pääsi mopo karkaamaan, kun hän kiitetyssä väitöskirjassaan Aboa vetus et nova (Vanha ja uusi Turku, 1700) esitti antiikin Rooman ja Kreikan sivistyksen olevan peräisin Suomesta. Jusleniuksen esikuva oli ruotsalainen monitieteilijä Olaus Rudbeck, jonka laajan historiateoksen mukaan Ruotsi oli koko ihmiskunnan alkukoti.

Taivalsaaren teoksen ulkopuolelta voi mainita, ettei kunniakkaan menneisyyden rakentaminen jäänyt 1600-1700-luvuille. Natsien SS-järjestön "tieteellinen" osasto Ahnenerben suunnitteli lähettävänsä retkikuntia kaikille mantereille hakemaan merkkejä maapalloa kansoittaneesta pohjoisesta vaaleasta rodusta, jonka kantaisät olivat astuneet esiin maailmankaikkeutta verhonneesta kosmisesta alkujäästä (Welteis; ks. Osmo Pekonen, Kasvatus \& Aika 1/15). Siinä hyhmeessä ei mukavuudenhaluinen etelän elävä olisi tarjennutkaan.

\section{MYKKYYDEN HENKI VALLITSEE}

Kansalliskirjaston perustajaa Henrik Gabriel Porthania (1739-
1804) voi yliopisto-opettajana pitää monipuolisena, koska hän luennoi latinan lisäksi siveysopista, luontaisesta oikeudesta, sielutieteestä, logiikasta, kasvatusopista, kirjallisuushistoriasta sekä yleisestä ja Venäjän historiasta. Yleiseurooppalaisen suuntauksen mukaisesti hän tutki myös tavallisen kansan elämää ja loi perustan suomalaiselle kansanrunouden tutkimukselle.

Jusleniuksen, Porthanin ja A.I. Arwidssonin esittelyn jälkeen seuraavat R. von Becker, A.J. Sjögren ja K.A. Gottlund tunnetuimpien kansallisten perustajaisien työn pohjustajana. Lönnrotin, Snellmanin ja kumppanien elämän ja tekojen esittelystä syntyy varsin eloisa kuva ajan keskusteluista. Ajankuvaa luo muun muassa 1800-luvun alkupuolen Turun ja Helsingin ilmapiirien vertailu. Edellisen ilmanalaa hallitsi kirkko ja papisto, jälkimmäistä valtio ja virkavalta. Ylioppilaillekin määrättiin virkapuku, mutta sen käyttöä oli vaikea valvoa. Yliopisto määrättiin pitämään kurinpitokirjaa, koska opiskelijoiden hankaukset patrullien kanssa ja tapojen puute, erityisesti "sikailulla rehvastelu" (s. 138) olivat uudelle pääkaupungille valitettavan leimallisia.

Vuonna 1830 Helsingissä oli vain yksi valtion koulu eli triviaalikoulu. Varakkaat eivät siihen jälkikasvuaan suostuneet laittamaan, 
koska opettajista monet olivat juoppoja tai epäpäteviä. "Mykkyyden henki vallitsi", muisteli Uno Cygnaeus myöhemmin opiskeluaikaansa. Tuolloin ei hänen mukaansa kuultu "kehoitusta pyrkiä yhteiseen päämäärään, mielenylennykseen, ajatella muinaisia aikoja ja toivoa jotakin tulevalta”.

Myös tavallisen suomalaisen kansan kelpaamattomuuden historia paikantuu kansallisen herätyksen aikaan. Eino Leino lausui vuonna 1912 vanhan Kalevalan 75-vuotisjuhlassa: "Suomen kansa ei kelpaa sellaisenaan. Tätä surullista totuutta ei voi toistaa liian useasti eikä liian äänekkäästi” (lain. s. 127). Lainauksesta ei selviä, mihin tai kenelle kansa ei tuolloin kelvannut, mutta myös Suomen EU-jäseneksi liittymisen aikaan kyseltiin jatkuvasti, millä ehdoilla "kelpaamme Eurooppaan”, ikään kuin olisimme olleet jossain muualla.

\section{SUURI LINJA HUKASSA}

Suomalaisuuden historia kuvataan Kansallinen herätys -teoksessa nykyhetkeen johtavana sivistyksen nousun ja rapautumisen suurena kertomuksena. Historian kertomuksen johdonmukaisuudesta tulee mieleen Raoul Palmgrenin (1912-1995) kansallisten herättäjien Venäjänäkemyksistä kertova teos Suuri linja vuodelta 1948. Tyylillises- ti erinomaista teosta kehui itse Kekkonen.

Palmgrenin seuraaja eli Oulun yliopiston kirjallisuustieteen professori Pertti Karkama totesi, että Palmgrenin "kritiikki pohjautui kansakunnan kaapin päälle asetettuihin patsasilmiöihin, ei suurmiehiin sinänsä. Palmgren piirsi uudet ideologiset muotokuvat. Ideologiset kertomukset on jokaisen sukupolven kirjoitettava uudestaan." Taivalsaaren teoksen voi nähdä juuri tällaisena ideologisena kertomuksena, mistä ominaisuudesta juontuu sen vahvuus ja myös pulmallisuus.

1900-luvun varjoja, kuten vuotta 1918 tai Lapuan liikkeen aikaisia tapahtumia luonnehditaan vaietuksi historiaksi, vaikka vaikenemisesta puhuminen ei enää ole täysin perusteltua. Onhan vähemmän mairittelevista Suomen historian käänteistä jo kirjoitettu paljonkin. Sen sijaan uudelleen hyvinkin ajankohtaiselta tuntuu lainaus Paavo Haavikolta: "Köyhyys on rikos, ja siitä rangaistaan" (lain. s. 259).

Nykyhetkeä lähestyttäessä kasvaa huoli katoavasta sivistyksestä, kapenevasta keskustelusta ja ympäristön riistosta. Nykyinen EU-Suomi näyttäytyy Potemkinin kulissina, jossa sananvapautta on niukemmin kuin 30-40 vuotta sitten (s. 315). Löytyy napakoita lausahduksia, kuten: "Miksi valtion kannattaa myydä sellaista, jota yksityisen kannattaa ostaa” (s. 322), tai: "Aatteet, arvot ja yhteiskunnallinen oikeudenmukaisuus on korvattu äänestäjien mielistelemisellä, joka muistuttaa vauvoille lepertelemistä" (s. 329). Tosin tätä kirjoitettaessa, eduskuntavaalien alla, puolueet näyttävät lepertelyn sijasta kilpailevan siitä, kenellä on pisin leikkauslista.

Teoksen päätösluvussa kirjoittaja tuo esiin ekovallankumouksen mahdollisuuden, jonka toteutumista helpottaa asukkaiden virran kääntyminen työttömyyden riivaamista kaupungeista takaisin maaseudulle ja perinteisten elinkeinojen piiriin.

Jussi Onnismaa dosentti, työnohjaajakouluttaja Kehityspiikki Consulting Oy 